\title{
MEMBANGUN SISTEM PERADILAN HUBUNGAN INDUSTRIAL YANG BERWIBAWA
}

\author{
Oleh:
}

\author{
Dr. Mashari, SH., MHum ${ }^{1}$
}

\begin{abstract}
Abstrak
Membangun sistem peradilan hubungan industrial mempunyai banyak dimensi dan keterkaitannya dengan kepentingan pengusaha, pemerintah, dan masyarakat. Salah satu fungsi lembaga Pengadilan Hubungan Industrial adalah untuk penyelesaian perselisihan hubungan industrial yang diakibatkan karena banyaknya kepentingan yang saling bertentangan. Permasalahan dalam penelitian sebagai berikut: (1) Bagaimana pelaksanaan penyelesaian perselisihan hubungan industrial melalui Pengadilan Hubungan Industrial ? (2) Bagaimana membangun sistem Peradilan Perselisihan Hubungan Industrial yang berwibawa ? Metode peneitian yang digunakan adalah socio legal research, yaitu penelitian yang melihat fenomena hukum dikaitkan dengan masalah yang terjadi di masyarakat dalam pelaksanaan penyelesaian perselisihan hubungan industrial melalui Pengadilan Hubungan Industrial sesuai UndangUndang Nomor 2 Tahun 2004 tentang Penyelesaian Perselisihan Hubungan Industrial. Hasil penelitian menunjukkan bahwa pelaksanaan penyelesaian perselisihan hubungan industrial melalui Pengadilan Hubungan Industrial kurang sesuai dengan konsep dan teori hukum yang berlaku pada umumnya. Konsep membangun sistem peradilan hubungan industrial yang berwibawa dimulai dengan perubahan secara kelembagaan terhadap sistem Undang-Undang Nomor 2 Tahun 2004 tentang Penyelesian Perselisihan Hubungan Industrial yang mengdopsi sistem penyelesaian perselisihan hubungan industrial dengan memberikan kewenangan penuh kepada Yudikatif. Perubahan secara kelembagaan ini diperlukan penyempurnaan diantaranya: penyempurnaan sistem satu atap; mengembangkan manajemen peradilan yang transparan dan akuntabel; rekruitmen Hakim; batas usia pensiun Hakim; Hakim Karier dan Non Karier; pentingnya pelembagaan eksaminasi putusan; dan perkuat fungsi pengawasan Komisi Yudisial. Selain itu juga para Hakim harus memiliki integritas dan profesionalisme untuk terwujudnya keadilan hukum bagi para pencari keadilan, terutama kalangan pekerja. Masalah sensitivitas hakim Pengadilan Hubungan Industrial terhadap persoalan buruh sangat diperlukan untuk penciptaan kondisi dan dukungan semua pemangku kepentingan (stake holders), termasuk negara dalam memberikan perhatian kesejahteraan kepada para hakim.
\end{abstract}

Kata kunci : Membangun Sistem, Peradilan Hubungan Industrial, Berwibawa

\section{Abstract}

Establishing an industrial relations court system has many dimensions and links to the interests of employers, governments and communities. One of the functions of the Industrial Relations Court is for the settlement of industrial relations disputes resulting from the multitude of conflicting interests. The following research issues are: (1) How is the implementation of industrial relations disputes settlement through the Industrial Relations

1 Mashari, Sekretaris Akademik Program Doktor Ilmu Hukum Fakultas Hukum UNTAG Semarang, tanggal 17 Oktober 2017. 
Court? (2) How to build an authoritative Industrial Dispute Court system? The research method used is socio legal research, the research that sees the legal phenomena associated with problems that occur in the community in the implementation of industrial relations dispute settlement through Industrial Relations Court in accordance with Law No. 2 of 2004 on Industrial Relations Dispute Settlement. The results show that the implementation of industrial relations dispute settlement through Industrial Relations Court is less in accordance with the concept and theory of law in general. The concept of establishing an authoritative industrial relations system begins with an institutional change to the system of Law No. 2 of 2004 on Industrial Relations Disputes adopting an industrial dispute resolution system by granting full authority to the Judiciary. This institutional change is needed to improve: one-stop system improvement; developing transparent and accountable judicial management; Judge recruitment; the retirement age of the Judge; Career and Non Career Judges; the importance of institutionalization of judicial exams; and strengthen the functions of the Judicial Commission's oversight. In addition, Judges must have integrity and professionalism for the realization of legal justice for the seeker of justice, especially among workers. The question of sensitivity of industrial relations court judges to labor issues is indispensable for the creation of conditions and support of all stake holders, including the state in giving welfare concerns to judges.

Keywords: System Building, Industrial Relations Court, Authoritative

\section{A. Latar Belakang Masalah}

Pembangunan nasional dilaksanakan dalam rangka pembangunan manusia Indonesia seutuhnya dan pembangunan masyarakat Indonesia seluruhnya untuk mewujudkan masyarakat yang sejahtera, adil, makmur, yang merata, baik materiil maupun spriritual berdasarkan Pancasila dan Undang-Undang Dasar Negara Republik Indonesia Tahun $1945 .^{2}$ Dalam pelaksanaan pembangunan nasional, tenaga kerja mempunyai peranan dan kedudukan yang sangat penting sebagai pelaku dan tujuan pembangunan. Peranan dan kedudukan tenaga kerja diperlukan pembangunan ketenagakerjaan untuk meningkatkan kualitas tenaga kerja dan peran sertanya dalam pembangunan serta peningkatan perlindungan tenaga kerja dan keluarganya sesuai dengan harkat dan martabat kemanusiaan.

Pembangunan ketenagakerjaan tidak hanya menyangkut pembentukan

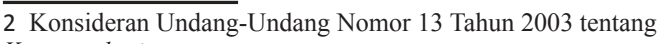
Ketenagakerjaan. hukum, tetapi juga adanya inkonsistensi dan ketidaksinkronan antar peraturan perundangan ketenagakerjaan yang seringkalimengakibatkan tumpang tindihnya peraturan, hal ini jelas melanggar prinsip kepastian hukum. ${ }^{3}$ Peraturan perundangan ketenagakerjaan mempunyai banyak dimensi dan keterkaitannya tidak hanya dengan kepentingan tenaga kerja sebelum, selama, dan sesudah masa kerja, tetapi juga dengan kepentingan pengusaha, pemerintah, dan masyarakat. Hal ini diperlukan pengaturan yang menyeluruh dan komprehensif, antara lain mencakup perencanaan tenaga kerja, pengembangan sumber daya manusia, perluasan kesempatan kerja, pelayanan penempatan kerja, pembinaan hubungan industrial, peningkatan perlindungan tenaga kerja, serta peningkatan produktivitas dan daya saing tenaga kerja di Indonesia.

Menciptakan hubungan industrial yang

3 Naoyuki Sakumoto, 1999, Labour Law And Policy In Indonesia, dalam Current Development Of Laws In Indonesia, Ed. Koesnadi Hardjasoemantri \& Naoyuki Sakumoto, Institute Of Developing Economies Japan External Trade Organization, Tokyo, hlm. 123. 
harmonis antara pekerja dan pengusaha tidaklah mudah, sering memicu terjadinya perselisihan hubungan industrial yang diakibatkan karena banyaknya kepentingan yangsalingbertentangan. Konflikkepentingan itu terjadi apabila dalam melaksanakan atau mengejar kepentingannya seseorang merugikan orang lain dan dalam kehidupan bersama konflik itu tidak dihindarkan. ${ }^{4}$ Hubungan industrial yang merupakan keterkaitan kepentingan antara pekerja dengan pengusaha, berpotensi menimbulkan perbedaan pendapat, bahkan perselisihan antara kedua belah pihak. Terjadinya perselisihan ini tentunya akan mengganggu dan mempengaruhi keseimbangan tatanan manusia dalam masyarakat, sehingga manusia selalu berusaha untuk menciptakan keseimbangan guna terciptanya suasana tertib, damai dan aman yang merupakan jaminan kelangsungan hidupnya.

Perselisihan hubungan industrial di era industrialiasasi menjadi semakin meningkat, kompleks dan mengandung berbagai aspek hukum, sehingga diperlukan institusi dan mekanisme penyelesaian perselisihan hubungan industrial yang cepat, tepat, adil dan murah. Oleh karena itu, diperlukan sistem penyelesaian perselisihan hubungan industrial yang diatur dengan undang-undang yang dapat mengakomodir penyelesaian semua bentuk perselisihan hubungan industrial, baik secara litigasi maupun non litigasi. Penyelesaian Perselisihan Hubungan Industrial sebagaimana diatur dalam Undang-Undang Nomor 2 Tahun 2004 tentang Penyelesaian Perselisihan Hubungan Industrial merupakan jawaban atas perbedaan pendapat yang mengakibatkan pertentangan antara pekerja dengan pengusaha, karena adanya perselisihan hak, perselisihan kepentingan, perselisihan pemutusan hubungan kerja, maupun

4 Sudikno Mertokusumo, 1996, Mengenal Hukum (Suatu Pengantar), Liberty, Yogyakarta, hlm. 4. perselisihan antar serikat pekerja/ serikat buruh dalam satu perusahaan.

Menurut data Ditjen Pengadilan Hubungan Industrial (PHI) Jamsos Kemenaker RI, per 31 Desember 2016, kasus Pemutusan Hubungan Kerja (PHK) yang terjadi ada sebanyak 1.554 kasus di tahun 2016, sementara kasus perselisihan yang muncul sebesar 1.320 kasus. Tingginya kasus PHK dan kasus perselisihan tersebut tentunya menjadi sebuah gambaran tentang kondisi riil hubungan industrial yang terjadi saat ini. ${ }^{5}$ Menurutnya, proses penyelesaian perselisihan hubungan industrial yang diatur dalam Undang Undang Nomor 2 Tahun 2004 tentang Penyelesian Perselisihan Hubungan Industrial, dan sudah beroperasi tiga belas tahun ini ternyata belum bisa menjawab kebutuhan kaum buruh untuk memperoleh proses penyelesaian yang cepat, tepat, adil dan murah.

Secara sistem Undang-Undang Nomor 2 Tahun 2004 tentang Penyelesian Perselisihan Hubungan Industrial mengdopsi sistem penyelesaian perselisihan hubungan industrial dengan memberikan kewenangan penuh kepada Yudikatif. Mekanisme penyelesaian melalui Bipartit dan Mediasi di luar kewenangan Yudikatif, maka produk proses tersebut tidak memiliki kekuatan hukum yang mengikat, berbeda dengan produk putusan Pengadilan Hubungan Industrial dan putusan di tingkat Mahkamah Agung yang sudah mengikat dan berkekuatan hukum bagi para pihak. Proses berjalannya persidangan di Pengadilan Hubungan Industrial dan Mahkamah Agung seluruhnya ditentukan oleh para Hakim, yaitu hakim karier dan hakim ad hoc (dari unsur Serikat Pekerja (SP)/Serikat buruh (SB) dan unsur pengusaha).

Kenyataannya berperkara di Pengadilan Hubungan Industrial merupakan upaya

5 Timboel Siregar, Selaku Sekjen Organisasi Pekerja Seluruh Indonesia (OPSI), Sabtu, tanggal 22 April 2016. 
hukum yang panjang dan berliku serta berbiaya tinggi. Kondisi penyelesaian perselisihan ini tidak sesuai dengan karakter penyelesaian perselisihan hubungan industrial yang berprinsip menjamin penyelesaian perselisihan dengan cepat, tepat, adil, dan biaya murah. Penyelesaian perselisihan hubungan industrial seharusnya pengadilan netral, yakni tidak memihak karenanya hakim yang memeriksa dan memutus suatu perkara perselisihan hubungan industrial haruslah orang-orang yang memiliki moralitas dan integritas tinggi. Sebagai contoh pekerja yang tersandung kesusahan sedang mencari keadilah di pengadilan kemudian harus kecewa karena tidak mendapatkan keadilan sebagaimana yang diinginkan. Ironisnya, hakim dan bahkan panitera terkadang memperlakukan seorang pekerja/buruh seperti layaknya pengusaha yang berduit. Berdasarkan uraian tersebut di atas, menarik untuk diteliti mengenai membangun sistem peradilan hubungan industrial yang berwibawa.

\section{B. Perumusan Masalah}

Berdasarkan latar belakang masalah tersebut di atas, maka dapat dirumuskan masalahnya sebagai berikut :

1. Bagaimana pelaksanaan penyelesaian perselisihan hubungan industrial melalui Pengadilan Hubungan Industrial ?

2. Bagaimana membangun sistem Peradilan Perselisihan Hubungan Industrial yang berwibawa?

\section{Pembahasan}

1. Pelaksanaan

Penyelesaian

Perselisihan Hubungan Industrial Melalui Pengadilan Hubungan Industrial

Penyelesaian perselisihan hubungan industrial secara litigasi melalui lembaga Pengadilan Hubungan Industrial, sebagaimana diatur dalam Undang-Undang
Nomor 2 Tahun 2004 tentang Penyelesaian Perselisihan Hubungan Industrial setelah dikaji lebih dalam ternyata masih kurang sesuai dengan konsep dan teori hukum yang berlaku pada umumnya. Hal ini disebabkan adanya perubahan sistem penyelesaian perselisihan hubungan industrial dari konsep hukum publik ke hukum privat yang harus diikuti dengan perubahan regulasi ketenagakerjaan yang lainnya. Terkait dengan perubahan tersebut, sangat dibutuhkan kearifan dari pemerintah dan pembuat peraturan perundang-undangan.

Penanganan perkara secara litigasi melalui lembaga Pengadilan Hubungan Industrial pada Pengadilan Negeri belum dapat dilaksanakan secara cepat, tepat, adil, dan murah. Hasil temuan peneliti mengenai penanganan perkara PHK di Pengadilan Hubungan Industrial pada Pengadilan Negeri Semarang sesuai ketentuan 50 hari kerja sudah mendapatkan putusan dari hakim, tetapi pratiknya penyelesaian perkara dari sidang pertama sampai dengan putusan menyita waktu sampai dengan 120 hari kerja lebih. Kondisi ini ironis dengan harapan Undang-Undang Nomor 2 Tahun 2004 tentang Penyelesaian Perselisihan Hubungan Industrial yang dapat menyelesaikan perselisihan hubungan industrial secara cepat, tepat, adil, dan murah.

Pelaksanaan penyelesaian perselisihan hubungan industrial secara non litigasi maupun yang litigasi belum dapat mewujudkan penyelesaian perselisihan hubungan industrial yang cepat, tepat, adil dan murah, hal ini disebabkan faktor-faktor yang diuraikan berikut ini.

a. Para pihak terbiasa menyelesaikan perselisihan hubungan industrial dengan melaporkan perkaranya di Disnaker/ Depnaker kemudian ditangani oleh P4D/ P4P, setelah berlakunya Undang-Undang Nomor 2 Tahun 2004 para pihak harus 
menyelesaikan perselisihan hubungan industrial sendiri di Pengadilan Hubungan Industrial, dan Mahkamah Agung.

b. Kapasitas hakim ad hoc dari unsur serikat pekerja/serikat buruh maupun dari unsur pengusaha, belum semuanya benarbenar memahami peraturan perundangundangan secara komprehensif.

c. Masalah rendahnya kemampuan konseptual para hakim ad hoc, baik dari substansi hukum maupun redaksional bahasanya dalam merumuskan suatu putusan yang benar-benar berdasarkan asas hukum dan keadilan.

d. Kapasitas hakim ad hoc, mereka ini mampu berdebat secara meyakinkan tetapi sampai pada tataran konseptual mereka bingung dan kedodoran.

e. Integritas hakim karier, disebabkan rendahnya tingkat kesejahteraan hakim dan faktor mentalitas akibat godaan pihak lain, sehingga menjadi "kebiasaan buruk" dalam menangani perkara dan akhirnya dapat menurunkan integritas.

f. Kinerja aparat Pengadilan disebabkan masih rendahnya penghasilan dan tingkat kesejahteraan aparat pengadilan, bahkan tidak sedikit ada aparat yang statusnya menjadi pegawai kontrak dengan kurun waktu yang cukup lama.

g. Ketersediaan anggaran Pengadilan Hubungan Industrial dan ketidakjelasan pemanfaatan, nampak belum adanya good will pemerintah untuk kelangsungan Pengadilan Hubungan Industrial.

h. Adanya intimidasi dari pengusaha terhadap saksi, yaitu karyawan perusahaan yang diminta pekerja/ buruh atau yang dipanggil hakim untuk menjadi saksi di persidangan Pengadilan Hubungan Industrial.

i. Lambannya penyelesaian perkara di Mahkamah Agung, disebabkan banyaknya kasus yang masuk dan ditangani di Mahkamah Agung sehingga harus menunggu sampai dengan putusan turun selama 1 (satu) tahun lebih.

Menurut Surya Tjandra bahwa Pengadilan Hubungan Industrial sebagai lembaga penyelesaian perselisihan yang ada di Indonesia saat ini dituntut tidak hanya harus adil dalam mengambil keputusan, tetapi juga harus sensitif dengan persoalan pekerja/ buruh, sebagai pihak yang paling lemah dalam hubungan perburuhan. Karakter perselisihan perburuhan, makin lama sebuah perkara selesai, makin tidak adil pula bagi buruh putusan yang akan dihasilkan.

Keadilan memang relatif adanya dan itu bukan berarti tidak mungkin bisa dicapai. Melalui profesionalisme hakim diharapkan keadilan dapat dicapai, yakni terwujudnya keadilan hukum bagi para pencari keadilan, terutama kalangan pekerja. Keadilan merupakan salah satu tujuan. hukum di samping kebenaran. Masalah sensitivitas hakim Pengadilan Hubungan Industrial terhadap persoalan buruh tentu sangat diperlukan. Persoalannya sensivitas itu tidak tumbuh secara otomatis dan begitu saja, tetapi perlu penciptaan kondisi dan dukungan semua pemangku kepentingan (stake holders), termasuk negara dalam memberikan perhatian kesejahteraan kepada para hakim.

Hakim merupakan sentral masalah karena ia yang menentukan menang dan kalahnya suatu perkara yang disengketakan. Melalui keputusan hakim masalah dapat terselesaikan dan dengan keputusannya 
masalah dapat semakin meruncing. ${ }^{6}$ Seorang hakim harus mempunyai sifat-sifat, yaitu percaya dan bertakwa kepada Tuhan Yang Maha Esa, adil, bijaksana, berbudi luhur, dan jujur. Selanjutnya seorang hakim seharusnya berani mati, seperti halnya Hakim Agung Safruddin yang tidak mau menerima sogokan demi menjunjung tinggi martabat hukum di mata masyarakat dan di hadapan Allah. Hakim yang tidak mau menegakkan kebenaran adalah hakim yang tidak berakhlak karimah, hakim yang bejat moralnya. Hakim yang enggan menegakan kebenaran dapat dipastikan ia adalah orang yang tidak jujur, yang tentu saja mau atau bahkan minta sogokan dari pihak yang bersengketa yang ingin dimenangkan perkaranya dalam persidangan.

Dalam melaksanakan tugasnya, Hakim mempunyai kebebasan dalam melaksanakan wewenang yudisial tidak mutlak sifatnya, dalam menegakkan keadilan berdasarkan Pancasila dengan jalan menafsirkan dan mencari dasar-dasar serta asas-asas yang menjadi landasannya melalui perkaraperkara yang dihadapinya, sehingga keputusannya mencerminkan perasaan keadilan bangsa dan rakyat Indonesia. ${ }^{7}$ Berdasarkan ketentuan Pasal 18 UndangUndang Nomor 48 Tahun 2009 disebutkan, bahwa kekuasaan kehakiman dilakukan oleh sebuah Mahkamah Agung dan badan peradilan yang berada di bawahnya dalam lingkungan peradilan umum, lingkungan peradilan agama, lingkungan peradilan militer, lingkungan peradilan tata usaha negara, dan oleh sebuah Mahkamah Konstitusi.

Dalam lingkungan peradilan umum,

6 Sholeh So'an, 2004, Moral Penegak Hukum di Indonesia (Pengacara, Hakim, Polisi, Jaksa) dalam Pandangan Islam, Cetakan I, Penerbit Agung Ilmu, Bandung, hlm. 130.

7 Sudikno Mertokusumo, 1998, Hukum Acara

Perdata Indonesia, Liberty, Yogyakarta, hlm. 92. terdapat pengkhususan berupa Pengadilan Lalu Lintas, Pengadilan Anak, Pengadilan Ekonomi, Pengadilan Niaga, Pengadilan Hak Asasi Manusia, dan Pengadilan Hubungan Industrial. Pengadilan Hubungan Industrial merupakan pengadilan khusus yang berada pada lingkungan peradilan umum sebagaimana disebukan oleh Pasal 55 UndangUndang Nomor 2 Tahun 2004. Kewenangan dari Pengadilan Hubungan Industrial adalah kewenangan mutlak atau kompetensi absolut dari Pengadilan Hubungan Industrial sebagaimana disebutkan dalam Pasal 56 Undang- Undang Nomor 2 Tahun 2004, yakni Pengadilan Hubungan Industrial bertugas dan berwenang memeriksa dan memutus:

a. Di tingkat pertama mengenai perselisihan hak.

b. Di tingkat pertama dan terakhir mengenai perselisihan kepentingan.

c. Ditingkat pertama mengenai perselisihan pemutusan hubungan kerja.

d. Di tingkat pertama dan terakhir mengenai perselisihan antara serikat pekerja/serikat buruh dalam satu perusahaan.

Perselisihan hak merupakan perselisihan normatif yang ditetapkan dalam perjanjian kerja, perjanjian kerja bersama, peraturan perusahaan, atau peraturan perundangundangan, maka penyelesaiannya tidak diberikan kepada konsiliasi maupun arbitrase, tetapi sebelum diajukan ke Pengadilan Hubungan Industrial terlebih dahulu melalui mediasi. Sementara perselisihan kepentingan merupakan perselisihan yang terjadi akibat perbedaan pendapat atau kepentingan mengenai keadaan ketenagakerjaan yang belum diatur dalam perjanjian kerja, perjanjian kerja bersama, peraturan perusahaan, atau peraturan perundangundangan. Perselisihan kepentingan ini pada tingkat pertama dan terakhir diputus 
oleh Pengadilan Hubungan Industrial pada Pengadilan Umum (tidak dimintakan kasasi ke Mahkamah Agung), hal ini dimaksudkan untuk menjamin penyelesaian yang cepat, tepat, adil, dan murah.

Pengadilan Hubungan Industrial ini dibentuk di Pengadilan Negeri dan pada Mahkamah Agung yang berwenang memeriksa, mengadili, dan memberikan putusan terhadap setiap penyelesaian perselisihan hubungan industrial. Pembentukan Pengadilan Hubungan Industrial pertama kali di Ibukota Propinsi. Secara bertahap, Pengadilan Hubungan Industrial akan dibentuk di Pengadilan Negeri yang berada di Kabupaten atau Kota yang padat industri. Susunan Pengadilan Hubungan Industrial pada Pengadilan Negeri terdiri dari Hakim, Hakim ad-hoc, Panitera Muda, dan Panitera Muda Pengganti.

Pembentukan Mahkamah Agung dan pengangkatan Hakim Agung, Hakim Agung ad-hoc, dan Panitera. Hakim Agung adalah hakim agung yang ditugaskan di Mahkamah Agung. Hakim Agung ad-hoc diangkat dan diberhentikan oleh Presiden atas usul serikat pekerja dan asosiasi pengusaha melalui Mahkamah Agung dan Menteri. Hal ini sama halnya dengan Hakim ad-hoc, Hakim Agung Ad-hoc dipilih untuk masa jabatan 5 (lima) tahun dan dapat diperpanjang maksimum satu periode. Hakim Agung Ad-hoc tidak boleh merangkap jabatan sebagai anggota lembaga tinggi negara, kepala daerah, pengacara, mediator, konsiliator, atau arbiter.

Pengangkatan hakim karier di Pengadilan Negeri untuk memeriksa perkara perselisihan industrial, dan diberhentikan oleh Ketua Mahkamah Agung. Sedangkan pengangkatan hakim ad-hoc adalah hakim Pengadilan Hubungan Industrial, dan diberhentikan oleh Presiden atas usulan serikat pekerja dan organisasi pengusaha melalui Ketua Mahkamah Agung dan Menteri. Selain itu pada masing-masing Pengadilan
Negeri diangkat 5 (lima) orang hakim ad-hoc mewakili unsur serikat pekerja dan 5 (lima) orang mewakili unsur asosiasi pengusaha. Hakim ad-hoc diangkat untuk masa tugas 5 (lima) tahun dan dapat diangkat kembali maksimum 1 (satu) kali masa jabatan. Hakim ad hoc tidak boleh merangkap jabatan sebagai anggota lembaga tinggi dan tertinggi negara, kepala daerah, pengacara, mediator, konsiliator, arbiter. Ketua Pengadilan Negeri mengawasi pelaksanaan tugas hakim, hakim ad-hoc, penitera muda dan panitera muda pengganti.

Mekanisme pengangkatan dan pemberhentian Hakim Ad-hoc pada Pengadilan Hubungan Industrial tidak terlepas dari peranan serikat pekerja/serikat buruh dan organisasi pengusaha. Kajian tentang implikasi dari proses yang demikian terhadap kemandirian Hakim Ad-hoc pada Pengadilan Hubungan Industrial dalam memeriksa, memutuskan dan menyelesaikan perselisihan hubungan industrial.

Menurut Iskandar $\mathrm{Kamil}^{8}$, apabila ditinjau dari rumusan pasal-pasal dalam Undang Undang Nomor 2 Tahun 2004 yang berkenaan dengan pengangkatan dan pemberhentian Hakim Ad-hoc dalam kaitannya dengan peranan serikat pekerja/ serikat buruh dan organisasi pengusaha. Selanjutnya kedua organisasi tersebut hanya "mengusulkan", dan tidak ada rumusan yang menyatakan bahwa Hakim Ad-hoc adalah wakil dari serikat pekerja/serikat buruh atau organisasi pengusaha yang mewakili kepentingan pihak yang mengusulkan.

Putusan seorang hakim harus berpihak dan berada dalam koridor hukum. Sedangkan keadilan merupakan implikasi dari adanya penegakan hukum tersebut. Seorang hakim dalam melakukan tugasnya tidak boleh bersikap diskriminatif, hanyut dalam

8 Iskandar Kamil, 2004, Kode Etik Profesi Hakim, Pedoman Perilaku Hakim (Code of Conduct), Kode Etik Hakim dan Makalah Berkaitan, Jakarta, Mahkamah Agung Republik Indonesia. 
perasaan/emosi. Dengan adanya penegakkan hukum tersebut berarti secara otomatis menegakan keadilan, karena hakikat yang paling utama dari hukum adalah keadilan. ${ }^{9}$ Seorang hakim juga harus dalam memutuskan suatu perkara, hakim agung harus benar-benar berdasarkan pada prinsip "Demi Keadilan Berdasarkan Ketuhanan Yang Maha Esa", bukan kepentingan politik tertentu. ${ }^{10}$

2. Kemandirian Hakim Ad-Hoc di Pengadilan Hubungan Industrial Berdasarkan Hukum dan Doktrin

Mekanisme pengangkatan dan pemberhentian Hakim Ad-Hoc, yang kesemuanya itu akan mempengaruhi tentang kemandirian dan profesionalisme sebagai seorang Hakim, terutama bagi Hakim AdHoc pada Pengadilan Hubungan Industrial, akan dilandasi dengan uraian landasan konstitional, landasan normatif dan argumentasi yang diperkuat dengan doktrin atas pendapat beberapa pakar tentang kemandirian hakim.

Kemandirian Hakim diperlukan pembenahan sistem melalui penyelenggaraan Sistem Peradilan Hubungan Industrial yang mendasarkan pada substansi hukum, struktur hukum, dan budaya hukum. Sejalan dengan konsep Friedman, maka sistem hukum terdiri dari 3 (tiga) elemen, yaitu elemen substansi (substance), struktur (structure), dan budaya hukum (legal culture). ${ }^{11}$ Penulis melihat pentingnya pembangunan sistem hukum di Indonesia pada aspek substansi

9 Muchsin, 2005, Keadilan dalam Penyelesaian Perselisihan Hubungan Industrial (Kajian Filosofis), Makalah pada Pelatihan Teknis Hakim Peradilan Umum tentang Perselisihan Hubungan Industrial, Jakarta, 26 Agustus 2005, hlm. 6. 10 Didi Irawadi Syamsuddin, Kekuasaan Kehakiman Hakim Agung jadi benteng terakhir, KOMPAS, Senin 12 September 2011, hlm. 2.

11 Lawrence M. Friedman, 2001, American Law An Introduction, Terj. Wishnu Basuki, Tatanusa, Jakarta, hlm. 8. sudah dilakukan dengan membentuk banyak norma mengenai perilaku masyarakat melalui peraturan perundang-undangan. Selanjutnya pada aspek struktur masih lemah, sebab aspek struktur inilah yang merupakan elemen yang akan menerapkan dan menegakan substansi hukum. Sedangkan aspek budaya hukum menyangkut sikap manusia terhadap hukum dan sistem hukum, termasuk di dalamnya kepercayaan, nilai, pemikiran serta harapannya.

Kajian sistem peradilan hubungan industrial, masih terdapat persoalan pada aspek struktur hukum diantaranya: kurangnya independensi kelembagaan hukum, akuntabilitas kelembagaan hukum, sumber daya manusia di bidang hukum dan sistem peradilan yang tidak transparan dan terbuka. Pembahasan mengenai kurangnya independensi kelembagaan hukum, terutama lembaga-lembaga penegak hukum juga membawa akibat besar dalam sistem hukum. Intervensi terhadap kekuasaan yudikatif, telah mengakibatkan terjadinya partialitas dalam berbagai putusan, walaupun hal seperti ini menyalahi prinsip-prinsip impartialitas dalam sistem peradilan.

Berbagai putusan-putusan yang meninggalkan prinsip impartialitas dalam jangka panjang telah berperan terhadap terjadinya degadrasi kepercayaan masyarakat kepada sistem hukum maupun hilangnya kepastian hukum. Pembinaan satu atap oleh Mahkamah Agung merupakan upaya untuk mewujudkan kemandirian kekuasaan kehakiman dan menciptakan putusan pengadilan yang tidak memihak (imparsial). Dalam rangka mendukung pembenahan sistem dan politik hukum, perlu menciptakan sistem hukum nasional yang adil, konsekuen, dan tidak diskriminatif. Dengan demikian penulis berpendapat pembangunan sistem peradilan dengan menekankan pada aspek struktur hukum melalui lembaga peradilan sangat penting dibandingkan aspek substansi dan kultur. 
Menurut Bagir Manan, bahwa sebagai suatu Negara yang berdasarkan atas hukum, Indonesia dalam menyelenggarakan tujuan negaranya, termasuk seluruh warga Negara harus bertindak sesuai dengan hukum dan dapat dipertanggungjawabkan secara hukum pula. Salah satu ciri dari Negara hukum adalah, kekuasaan yang merdeka untuk menyelenggarakan peradilan dalam rangka menegakan hukum dan keadilan yang bebas dari campur tangan pihak kekuasaan pemerintah. Kekuasaan kehakiman yang merdeka merupakan salah satu pilar untuk memulihkan demokrasi atau Negara hukum. ${ }^{12}$

Selanjutnya dalam tulisan Bagir Manan dijelaskan bahwa kekuasaan kehakiman yang merdeka mengandung beberapa pilar dan tujuan dasar sebagai berikut :

1. Sebagai badan dari system pemisahan atau pembagian kekuasaan diantara badan-badan penyelenggara Negara, kekuasaan kehakiman yang merdeka diperlukan untuk menjamin dan melindungi kepentingan individu.

2. Kekuasaan kehakiman yang merdeka diperlukan untuk mencegah penyelenggara pemerintah bertindak secara semena-mena dan menindas.

3. Kekuasaan kehakiman yang merdeka diperlukan untuk dapat menilai keabsahan secara hukum tindakan pemerintah atau suatu peraturan perundang-undanan sehingga sistem hukum dapat dijalankan dan ditegakkan secara baik, dan

4. Kekuasaan kehakiman yang merdeka hanya akan berkembang dalam Negara yang demokratis dan egaliter

12 Bagir Manan, 2004, Sistem Peradilan Berwibawa (Suatu Pencarian), Mahkamah Agung RI, Jakarta, hlm. 145. (persamaan). Tanpa demokrasi akan lumpuh dan menjadi instrument kekuasaan belaka. ${ }^{13}$

Menurut R. Tresna bahwa berdasarkan hukum positif, terdapat jaminan-jaminan bagi peradilan yang baik, yang dapat dibagi dalam beberapa golongan sebagai berikut :

a. yang terletak di dalam syarat-syarat yang mengenai kepribadian hakim, seperti syarat-syarat tentang kecakapan, kepandaian dan kelakuan.

b. yang terletak di dalam syarat-syarat yang mengenai kedudukan hakim, seperti tentang pengangkatan dan pemberhentian.

c. yang terletak di dalam keharusan bagi pengadilan untuk menjalankan tugasnya secara bebas.

d. yang terletak di dalam tata cara pemeriksaan perkara di muka pengadilan sebagai jaminan untuk tertib dan teratur serta terbuka untuk umum.

e. yang terletak di dalam jaminan-jaminan bagi rakyat untuk mencapai keadilan dan diperlakukan secara adil. ${ }^{14}$

Kemandirian hakim merupakan hal yang mutlak untuk mewujudkan keadilan bagi masyarakat pencari keadilan, apalagi dalam perselisihan hubungan industrial, di mana putusan yang ditetapkan oleh Majelis Hakim Pengadilan Hubungan Industrial, dapat berimplikasi pada iklim investasi dan nasib pekerja/buruh beserta keluarganya. Oleh sebab itu putusan tersebut haruslah mencerminkan keadilan yang dapat menyeimbangkan antara iklim investasi dan

13 Bagir Manan, 1999, Kekuasaan Kehakiman yang merdeka, Mimbar Hukum, No.43, Tahun X, hIm..10.

14 R. Tresna, 1978, Peradilan di Indonesia dari Abad ke Abad, Jakarta, Pradnya Paramita, hlm.143. 
kepentingan pekerja/buruh yang umumnya lemah.

3. Konsep Membangun Sistem Peradilan Perselisihan Hubungan Industrial Yang Berwibawa

Keberadan lembaga penyelesaian perselisihan perburuhan sebelum diundangkannya Undang-Undang Nomor 2 Tahun 2004 adalah Panitia Penyelesaian Perselisihan Perburuhan (P4), lembaga tersebut sebagai lembaga arbitrase, terutama arbitrase wajib yang diselenggarakan oleh pemerintah, memiliki peranan yang paling besar. Lembaga penyelesaian perselisihan perburuhan pada saat itu hanya $\mathrm{P} 4$, karena hampir seluruh perselisihan perburuhan dimintakan penyelesaiannya kepada lembaga ini. Sementara keberadaan Pengadilan Negeri peranannya kecil sekali, karena Pengadilan Negerisering kalibersikap menolak menerima, memeriksa dan Pengertian Pengadilan Hubungan Industrial menurut konsepsi
Pasal 1 Undang-Undang Nomor 2 Tahun 2004, diartikan bahwa Pengadilan Hubungan Industrial adalah pengadilan khusus yang dibentuk di lingkungan Pengadilan Negeri yang berwenang memeriksa, mengadili dan memberi putusan terhadap perselisihan hubungan industrial.

Kewenangan Pengadilan Hubungan Industrial pada Pengadilan Negeri dalam penyelesaian perselisihan hubunganindustrial sebagaimana diatur dalam Undang-Undang Nomor 2 Tahun 2004 tentang Penyelesaian Perselisihan Hubungan Industrial masih banyak kelemahannya, baik penyelesaian perselisihan secara non litigasi maupun secara litigasi. Kondisi demikian diperlukan upaya komprehensif pembangunan sistem peradilan hubungan industrial yang berwibawa secara litigasi melalui lembaga Pengadilan Hubungan Industrial, dan secara non litigasi melalui lembaga Bipartit, Mediasi, Konsiliasi, Arbitrase, utuk mengatasi masalah perselisihan hubungan industrial dan dicarikan solusinya.

Membangun Sistem Peradilan Hubungan Industrial Yang Berwibawa dan Berkeadilan

\begin{tabular}{|c|c|c|c|}
\hline No & MASALAH & PENYEBAB & ALTERNATIF SOLUSI \\
\hline (1) & (2) & (3) & (4) \\
\hline 1 & $\begin{array}{l}\text { Kualitas penyelesa } \\
\text { ian mediasi di instansi } \\
\text { bidang ketenagakerjaan }\end{array}$ & $\begin{array}{l}\text { a. Kurangnya } \\
\text { pemahaman oleh } \\
\text { sebagian mediator } \\
\text { terhadap UU } \\
\text { Ketenagakerjaan. }\end{array}$ & $\begin{array}{l}\text { Peningkatan kapasitas } \\
\text { melalui pelatihan } \\
\text { dasar-dasar hukum } \\
\text { ketenagakerjaan, } \\
\text { sehingga penyelesaian } \\
\text { mediasi (khususnya } \\
\text { materi anjuran) } \\
\text { berdasarkan dan } \\
\text { sesuai dengan } \\
\text { asas-asas hukum } \\
\text { ketenagakerjaan. }\end{array}$ \\
\hline
\end{tabular}




\begin{tabular}{|c|c|c|c|}
\hline No & MASALAH & PENYEBAB & ALTERNATIF SOLUSI \\
\hline \multirow[t]{2}{*}{ (1) } & (2) & (3) & (4) \\
\hline & & $\begin{array}{l}\text { b. Penempatan } \\
\text { aparat di bidang } \\
\text { ketenagakerjaan } \\
\text { (termasuk mediator) } \\
\text { tidak sesuai dengan } \\
\text { kompetensi teknis } \\
\text { yang dibutuhkan. }\end{array}$ & $\begin{array}{l}\text { Perlunya political wil } \\
\text { dan gubemur/bupati/wali } \\
\text { kota terhadap penempatan } \\
\text { aparat ketenagakerjaan } \\
\text { yang sesuai dengan } \\
\text { kompetensi teknis yang } \\
\text { dibutuhkan di bidang } \\
\text { ketenagakerjaan. }\end{array}$ \\
\hline \multirow[t]{2}{*}{2} & $\begin{array}{l}\text { Kurangnya pemahaman } \\
\text { para pihak dalam praktik } \\
\text { beracara di Pengadilan } \\
\text { Hubungan Industrial }\end{array}$ & $\begin{array}{l}\text { a. Kebiasaan } \\
\text { meng- urus kasus } \\
\text { perselisihan di } \\
\text { Disnaker/ Depnaker } \\
\text { dan ber- perkara di } \\
\text { P4D/P4P. }\end{array}$ & $\begin{array}{l}\text { a. Pelatihan teknis } \\
\text { beracara di pengadilan } \\
\text { hubungan industrial, } \\
\text { termasuk penyusunan } \\
\text { dokumentasi hukum } \\
\text { beracara. }\end{array}$ \\
\hline & & $\begin{array}{l}\text { b. Minimnya } \\
\text { pengetahuan dan } \\
\text { praktik beracara di } \\
\text { pengadilan karena } \\
\text { masih minimnya } \\
\text { inten sitas sosialisasi } \\
\text { teknik beracara di } \\
\text { Pengadilan Hu- } \\
\text { bungan Industrial. }\end{array}$ & $\begin{array}{l}\text { b. Penyuluhan berkala } \\
\text { bagi serikat pekerja/ } \\
\text { serikat buruh dan } \\
\text { pengusaha. }\end{array}$ \\
\hline \multirow[t]{2}{*}{3} & $\begin{array}{l}\text { Kapasitas dan integritas } \\
\text { hakim ad hoc }\end{array}$ & $\begin{array}{l}\text { a. Kurangnya } \\
\text { pemahaman } \\
\text { sebagian hakim ad } \\
\text { hoc terhadap UU } \\
\text { ketenagakerjaan } \\
\text { secara komprehensif. }\end{array}$ & $\begin{array}{l}\text { Seleksi yang ketat } \\
\text { sejak dari tingkat } \\
\text { daerah, mulai hal } \\
\text { pemahaman UU } \\
\text { Ketenagakerjaan, } \\
\text { kemampuan } \\
\text { konseptual, hingga } \\
\text { masalah track record } \\
\text { sebelumnya. }\end{array}$ \\
\hline & & $\begin{array}{l}\text { b. Track record hakim } \\
\text { ad hoc. }\end{array}$ & \\
\hline
\end{tabular}


Dr. Mashari, SH., MHum : MEMBANGUN SISTEM PERADILAN HUBUNGAN INDUSTRIAL YANG BERWIBAWA

\begin{tabular}{|c|c|c|c|}
\hline No & MASALAH & PENYEBAB & ALTERNATIF SOLUSI \\
\hline \multirow[t]{2}{*}{ (1) } & (2) & (3) & (4) \\
\hline & & $\begin{array}{l}\text { c. Rendahnya } \\
\text { kemampuan } \\
\text { konseptual } \\
\text { merumuskan putusan. } \\
\text { d. Lemahnya integritas, } \\
\text { yang salah satunya } \\
\text { akibat rendah- nya } \\
\text { tingkat kesejahteraan. }\end{array}$ & $\begin{array}{l}\text { a. Pembinaan, baik dari } \\
\text { MA maupun dari } \\
\text { kelembagaan unsur } \\
\text { yang mengusulkan } \\
\text { sehingga tidak } \\
\text { terkontaminasi "citra } \\
\text { buram" di pengadilan. } \\
\text { b. Penerapan sanksi yang } \\
\text { tegas terhadap hakim- } \\
\text { hakim nakal. }\end{array}$ \\
\hline \multirow[t]{3}{*}{4} & \multirow[t]{3}{*}{ Integritas hakim karier } & $\begin{array}{l}\text { a. Rendahnya tingkat } \\
\text { kesejahteraan. }\end{array}$ & $\begin{array}{l}\text { Perlu kebijakan } \\
\text { tentang peningkatan } \\
\text { kesejahteraan hakim } \\
\text { serta penerapan } \\
\text { sanksi yang tegas } \\
\text { terhadap hakim- } \\
\text { hakim yang nakal. }\end{array}$ \\
\hline & & $\begin{array}{l}\text { b. Kebiasaan "buruk" } \\
\text { dalam menangani } \\
\text { perkara perdata dan } \\
\text { pidana. } \\
\text { c. Mentalitas hakim. }\end{array}$ & $\begin{array}{l}\text { a. Kontrol yang ketat } \\
\text { dan semua pemangku } \\
\text { kepentingan } \\
\text { (stakeholders). }\end{array}$ \\
\hline & & & $\begin{array}{l}\text { b. Perlunya sosialiasi } \\
\text { kesadaran menghapus } \\
\text { perilaku menyogok } \\
\text { bagi para pencari } \\
\text { keadilan (pekerja/ } \\
\text { buruh, SP/SB, dan } \\
\text { pengusaha). }\end{array}$ \\
\hline
\end{tabular}




\begin{tabular}{|c|c|c|c|}
\hline No & MASALAH & PENYEBAB & ALTERNATIF SOLUSI \\
\hline (1) & (2) & (3) & (4) \\
\hline 5 & Kinerja aparat pengadilan & $\begin{array}{l}\text { a. Rendahnya } \\
\text { penghasilan dan } \\
\text { kesejahteraan. }\end{array}$ & $\begin{array}{l}\text { Perlu kebijakan } \\
\text { tentang peningkatan } \\
\text { kesejahteraan aparat } \\
\text { pengadilan.serta } \\
\text { penerapan sanksi yang } \\
\text { tegas terhadap aparat } \\
\text { pengadilan yang nakal. }\end{array}$ \\
\hline & & $\begin{array}{l}\text { b. Masih adanya biaya } \\
\text { untuk pengurusan } \\
\text { perkara di PHI, khu- } \\
\text { susnya pendaftaran } \\
\text { perjanjian bersama, } \\
\text { akta perdamaian, } \\
\text { surat kuasa, dan } \\
\text { pendaftaran kasasi. }\end{array}$ & $\begin{array}{l}\text { a. Perlu adanya } \\
\text { keberanian dari para } \\
\text { pihak untuk melapor } \\
\text { ke Ketua PN/PHI dan } \\
\text { Mahkamah Agung. }\end{array}$ \\
\hline & & $\begin{array}{l}\text { c. Lambannya pengi- } \\
\text { riman berkas kasa- } \\
\text { si ke Mahkamah } \\
\text { Agung. }\end{array}$ & $\begin{array}{l}\text { b. Perlunya sanksi tegas } \\
\text { bagi aparat yang } \\
\text { melanggar. } \\
\text { Adanya sanksi tegas } \\
\text { terhadap panitera yang } \\
\text { sengaja melaksanakan } \\
\text { tugas }\end{array}$ \\
\hline 6 & $\begin{array}{l}\text { Ketersediaan anggaran } \\
\text { PHI dan ketidakjelasan } \\
\text { pemanfaatan }\end{array}$ & $\begin{array}{l}\text { a. Komitmen } \\
\text { pemerintah. }\end{array}$ & $\begin{array}{l}\text { Perubahan kebijakan } \\
\text { politik dan good } \\
\text { will dari pemerintah, } \\
\text { termasuk Mahkamah } \\
\text { Agung terhadap } \\
\text { kelangsungan } \\
\text { Pengadilan Hubung- } \\
\text { an Industrial dalam } \\
\text { sistem peradilan. }\end{array}$ \\
\hline
\end{tabular}




\begin{tabular}{|c|c|c|c|}
\hline No & MASALAH & PENYEBAB & ALTERNATIF SOLUSI \\
\hline \multirow[t]{2}{*}{ (1) } & (2) & (3) & (4) \\
\hline & & $\begin{array}{l}\text { b. Tidak transparan, dan } \\
\text { dimanfaatkan untuk } \\
\text { kebutuhan di luar } \\
\text { PHI. }\end{array}$ & $\begin{array}{l}\text { a. Perlu audit secara } \\
\text { sungguhsungguh dari } \\
\text { instansi berwenang } \\
\text { atas penggunaan ang- } \\
\text { garan PHI. } \\
\text { b. Perlu keberanian } \\
\text { kontrol internal dari } \\
\text { para hakim ad hoc } \\
\text { terhadap anggaran } \\
\text { PHI sebagai dana } \\
\text { publik. }\end{array}$ \\
\hline \multirow[t]{2}{*}{7} & \multirow[t]{2}{*}{$\begin{array}{l}\text { Adanya intimidasi dari } \\
\text { pengusaha terhadap } \\
\text { saksi (karyawan } \\
\text { perusahaan) yang diminta } \\
\text { pekerjaiburuh atau yang } \\
\text { di- panggil hakim untuk } \\
\text { menjadi saksi di persi- } \\
\text { dangan Peng- adilan } \\
\text { Hubung- an Industrial }\end{array}$} & $\begin{array}{l}\text { a. Rasa ketakutan } \\
\text { yang berlebihan dan } \\
\text { arogansi pengusaha. }\end{array}$ & $\begin{array}{l}\text { a.Penyuluhan } \\
\text { peningkatan kesadaran } \\
\text { hukum terhadap } \\
\text { pengusaha. } \\
\text { b.Pertemuan tripartit } \\
\text { dengan melibatkan } \\
\text { haki PHI. }\end{array}$ \\
\hline & & $\begin{array}{l}\text { b. Kredibilitas saksi di } \\
\text { mata pengusaha. }\end{array}$ & $\begin{array}{l}\text { a. Komunikasi intensif } \\
\text { dan penjelasan dari } \\
\text { saksi (Karyawan) } \\
\text { kepada pengusaha. } \\
\text { b. Adanya "keberanian" } \\
\text { dari } \\
\text { saksi untuk bersikap } \\
\text { benar dalam } \\
\text { menegakkan hukum } \\
\text { dan keadilan. }\end{array}$ \\
\hline
\end{tabular}




\begin{tabular}{|c|c|c|c|}
\hline No & MASALAH & PENYEBAB & ALTERNATIF SOLUSI \\
\hline$(1)$ & (2) & (3) & (4) \\
\hline 8 & $\begin{array}{l}\text { Lambannya penyelesaian } \\
\text { proses kasasi di } \\
\text { Mahkamah Agung }\end{array}$ & $\begin{array}{l}\text { Putusan MA harus } \\
\text { menunggu hingga } \\
1 \text { (satu) tahun baru } \\
\text { diterima oleh para pihak } \\
\text { di daerah. }\end{array}$ & $\begin{array}{l}\text { Upaya hukum } \\
\text { penyelesaian perselisihan } \\
\text { diubah dari Mahkamah } \\
\text { Agung ke Pengadilan } \\
\text { Tinggi (sebagai upaya } \\
\text { hukum terakhir dan } \\
\text { berkekuatan hukum } \\
\text { tetap). }\end{array}$ \\
\hline
\end{tabular}

Sumber : Hasil Penelitian Diadopsi dari Abdul Khakim yang diolah. ${ }^{15}$

Permasalahan pelaksanaan penyelesaian perselisihan hubungan industrial tersebt di atas menunjukkan bahwa Undang-Undang Nomor 2 Tahun 2004 tentang Penyelesaian Perselisihan Hubungan Industrial masih banyak kelemahannya, baik penyelesaian perselisihan secara non litigasi maupun secara litigasi. Menurut Surya Tjandra, bahwa proses hukum tidaklah berhenti dengan disahkannya sebuah undang-undang yang mengatur hal tertentu. ${ }^{16}$ Aspek instrumental dari undang-undang mensyaratkan adanya tindakan penegakan, proses pemeriksaan dan penyelesaian formal (adjudication) apabila terjadi perselisihan. Contohnya, pelaksanaan fungsi pengawasan negara terkait isu perburuhan yang cenderung ditekankan bukan pada penghukuman (penal), melainkan lebih pada peran konsiliasi (consiliatory) dari legislasi, sebagai alat mewujudkan yang disebut dengan kedamaian industrial.

15 Diadopsi dari Abdul Khakim, 2010 Aspek Hukum Penyelesaian Perselisihan Hubungan Industrial (Antara Peraturan dan Pelaksanaan), PT. Citra Aditya Bakti, Bandung, hlm. 114-117.

16 Surya Tjandra, 2007, Praktek Pengadilan Hubungan Industrial: Panduan Bagi Serikat Buruh, Cetakan I, Penerbit Trade Union Rights Centre (TURC), Jakarta, hlm. x.
Menurut T. Gayus Lumbun secara sistematis dan komprehensif dalam membangun peradilan hubungan industrial yang berwibawa, yaitu: ${ }^{17}$

\section{Penyempurnaan Sistem Satu Atap}

Salah satu agenda penting yang mendukung independensi kekuasaan kehakiman adalah kebijakan "satu atap". Kebijakan ini mengalihkan urusan teknis administrative kekuasaan kehakiman dari Kementerian Kehakiman yang merupakan bagian dari eksekutif ke Mahkamah Agung sendiri yang berada di bawah kekuasaan yudikatif sendiri.

2. Mengembangkan Manajemen Peradilan yang Transparan dan Akuntabel

Manajemen Peradilan yang transparan dan akuntabel harus dimulai dari pembenaan organisasi yang mampu menampilkan diri dalam perspektif pembenahan independensi atau kemandirian kekuasaan kehakiman, baik kemandirian institusi, maupun kemandirian individu hakim, mulai dari hakim pada tingkat Pengadilan Negeri sampai pada Hakim Agung Mahkamah Agung.

\section{Rekruitmen Hakim}

17 T. Gayus Lumbun, Makalah Seminar "Membangun Sistem Peradilan Yang Bebas Mafia”, Diselenggarakan oleh Fakultas Hukum Universitas 17 Agustus 1945 (UNTAG) Semarang, Dalam Rangka dies Natalis Fakultas hukum UNTAG Semarang, tanggal 10 September 2016. 
Suatu rekruitmen Hakim sangat penting dan strategis. Selain mekanisme rekruitmen yang transparan namun yang paling subtantif dan komprehensif para hakim adalah syarat-syarat untuk menjadi hakim harus diperkuat.

\section{Batas Usia Pensiun Hakim}

Batas usia Hakim Agung maupun untuk Hakim pada tingkat Pengadilan Negeri dan Pengadilan Tinggi. Pengurangan batas usia pension disamping dimaksudkan untuk regenerasi hakim, juga berkaitan dengan produktivitas hakim, yang dipengaruhi factor usia dan ksehatan.

5. Hakim Karier dan Non Karier

Dalam perspektif penguatan lembaga peradilan, maka Hakim Non Karier sangat diperlukan untuk memperkuat lembaga peradilan. Berdasarkan pola rekruitmen terbuka dan evaluasi terhadap Hakim Agung yang dilakukan setiap lima tahun, maka dikotomi hakim karier dan non karier sudah tidak relevan lagi.

6. Pentingnya Pelembagaan Eksaminasi Putusan

Eksaminasi terhadap suatu putusan pengadilan merupakan bentuk control public (social control) terhadap suatu proses penegakan hukum melalui pengadilan. Eksaminasi hanya merupakan salah satu saja dari bentuk pengawasan di lingkungan pengadilan, karena selain eksaminasi masih terdapat bentuk pengawasan lain baik secara internal maupun eksternal sebagaimana telah diuraikan sebelumnya.

7. Perkuat Fungsi Pengawasan Komisi Yudisial

Saat ini masih dirasakan hubungan antara Mahkamah Agung dan Komisi Yudisial yang kurang harmonis. Penulis berpendapat Mahkamah Agung harus menerima keberadaan Komisi Yudisial sebagai lembaga Negara yang diakui Konstitusi. Keberadaan Komisi Yudisial jangan dilihat sebagai institusi yang mengganggu kemapanan Mahkamah Agung tetapi justru menjadi lembaga yang dapat membantu memperbaiki dan menjaga citra Mahkamah Agung dan badan-badan peradilan di bawahnya.

Dalam mewujudkan sistem peradilan yang berwibawa, maka diperlukan integritas dan profesionalisme hakim, yakni terwujudnya keadilan hukum bagi para pencari keadilan, terutama kalangan pekerja. Masalah sensitivitas hakim Pengadilan Hubungan Industrial terhadap persoalan buruh tentu sangat diperlukan. Persoalannya sensivitas itu tidak tumbuh secara otomatis dan begitu saja, tetapi perlu penciptaan kondisi dan dukungan semua pemangku kepentingan (stake holders), termasuk negara dalam memberikan perhatian kesejahteraan kepada para hakim.

\section{Kesimpulan}

Berdasarkan uraian pembahasan tersebut di atas, maka dapat disimpulkan sebagai berikut :

1. Pelaksanaan penyelesaian perselisihan hubungan industrial melalui Pengadilan Hubungan Industrial kurang sesuai dengan konsep dan teori hukum yang berlaku pada umumnya. Konsep perubahan sistem penyelesaian perselisihan hubungan industrial dari konsep hukum publik ke hukum privat yang harus diikuti dengan perubahan regulasi ketenagakerjaan yang lainnya. Terkait dengan perubahan tersebut, sangat dibutuhkan kearifan dari pemerintah dan pembuat peraturan perundangundangan. Mekanisme penanganan perkara secara litigasi melalui lembaga Pengadilan Hubungan Industrial pada Pengadilan Negeri belum dapat dilaksanakan secara cepat, tepat, adil, dan murah. Hal ini disebabkan masih kurangnya independensi kelembagaan hukum, akuntabilitas kelembagaan hukum, sumber daya manusia di bidang hukum dan sistem peradilan yang tidak transparan dan 
Industrial (Antara Peraturan dan Pelaksanaan), PT. Citra Aditya Bakti, Bandung.

Bagir Manan, 2004, Sistem Peradilan Berwibawa (Suatu Pencarian), Mahkamah Agung RI, Jakarta.

Iskandar Kamil, 2004, Kode Etik Profesi Hakim, Pedoman Perilaku Hakim (Code of Conduct), Kode Etik Hakim dan Makalah Berkaitan, Jakarta, Mahkamah Agung Republik Indonesia.

Lawrence M. Friedman, 2001, American Law An Introduction, Terj. Wishnu Basuki, Tatanusa, Jakarta.

Muchsin, 2005, Keadilan dalam Penyelesaian Perselisihan Hubungan Industrial (Kajian Filosofis), Makalah pada Pelatihan Teknis Hakim Peradilan Umum tentang Perselisihan Hubungan Industrial, Jakarta, 26 Agustus 2005.

Mashari, Sekretaris Akademik Program Doktor Ilmu Hukum Fakultas Hukum UNTAG Semarang, tanggal 17 Oktober 2017.

Naoyuki Sakumoto, 1999, Labour Law And Policy In Indonesia, dalam Current Development of Laws In Indonesia, Ed. Koesnadi Hardjasoemantri \& Naoyuki Sakumoto, Institute Of Developing Economies Japan External Trade Organization, Tokyo.

R. Tresna, 1978, Peradilan di Indonesia dari Abad ke Abad, Jakarta, Pradnya Paramita.

Sholeh So'an, 2004, Moral Penegak Hukum di Indonesia (Pengacara, Hakim, Polisi, Jaksa) dalam Pandangan Islam, Cetakan I, Penerbit Agung Ilmu, Bandung.
Sudikno Mertokusumo, 1996, Mengenal Hukum (Suatu Pengantar), Liberty, Yogyakarta.

Acara Perdata Indonesia, Liberty,
Yogyakarta.

Surya Tjandra, 2007, Praktek Pengadilan Hubungan Industrial: Panduan Bagi Serikat Buruh, Cetakan I, Penerbit Trade Union Rights Centre (TURC), Jakarta.

T. Gayus Lumbun, Makalah Seminar "Membangun Sistem Peradilan Yang Bebas Mafia", Diselenggarakan oleh Fakultas Hukum Universitas 17 Agustus 1945 (UNTAG) Semarang, Dalam Rangka dies Natalis Fakultas hukum UNTAG Semarang, tanggal 10 September 2016.

Timboel Siregar, Selaku Sekjen Organisasi Pekerja Seluruh Indonesia (OPSI), Sabtu, tanggal 22 April 2016.

\section{Peraturan Perundang-Undangan :}

Undang-Undang Dasar Negara Republik

Indonesia Tahun 1945

Undang-Undang Nomor 13 Tahun 2003

tentang Ketenagakerjaan.

Undang-Undang Nomor 2 Tahun 2004 tentang Penyelesaian Perselisihan Hubungan Industrial.

\section{Jurnal/Koran :}

Bagir Manan, 1999, Kekuasaan Kehakiman yang merdeka, Mimbar Hukum, No.43, Tahun X.

Didi Irawadi Syamsuddin, Kekuasaan Kehakiman Hakim Agung jadi Benteng Terakhir, KOMPAS, Senin 12 
Dr. Mashari, SH., MHum : MEMBANGUN SISTEM PERADILAN HUBUNGAN INDUSTRIAL YANG BERWIBAWA

September 2011. 